\title{
THE IDEA OF ONE WAY WORD FORMATION DICTIONARY
}

\author{
Irina Kovyneva, Kursk State Medical University, ir_kov@yahoo.com
}

In the modern word formative theory of neologisms there is practically no description of concrete unusual occasional way of word formation, such as holophrasis, gendiadis, decomposition and others. There is also no dictionary, describing one of these types of word composition. There are two specific questions, which occur with the process of creation of one way word formation (holophrase) dictionary: 1) how to introduce the holophrastic construction (HC) into the dictionary; 2) the context of usage of HC. Though HC is polycomponental, the introduction should be only one - by the first word in the construction. The context of usage of $\mathrm{HC}$ is usually limited by the sentence, in which $\mathrm{HC}$ is used. The $\mathrm{HC}$ dictionary emphasizes the new opening in the philosophic understanding of the sense of meaning and its connection with the lexicographic semantisation.

UDC Number: 81`37, DOI: 10.12955/cbup.2013.30

Keywords: neologism, holophrases, context, word article, occasional words.

\section{Introduction}

The end of $20^{\text {th }}$ - the beginning of $21^{\text {st }}$ century is a time of lexicographic boom. Different kinds of dictionaries are being published: the authors' dictionaries; the dialect words dictionaries; the combined dictionaries, describing the lexical stuff of the different authors' handiworks, based on this or that type. As Dubichinsky (2008) writes: "The dictionary - is a product of epoch. Its creation depends a lot on the concrete historical and cultural conditions, on the development of the theoretical linguistic and other sciences, on the textual materials, which the linguists use. But it is well known that these conditions, which form the "epoch", are very changeable. So, as a result of this, it is possible to expect the termless future of the lexicography". (Dubichinsky, 2008)

\section{Literature review}

The new words (neologisms) appear in the language every day in huge number, naming the new things and processes. The task of the linguists is to find, describe and define the new words. For understanding the meaning of the new word it is also very important to show, what way of word formation the neologism was created by. How and why the neologism appears and functions in the language?

„Basically, a new word comes into a language through creatively using that language“. (The Urban dictionary, 1999)

"Neologisms are invented words. We are particularly interested in invented words which represent concepts or objects that didn't previously exist". (The International Dictionary of Neologisms, 1991) 
As Ahmad (2000) writes about different ways of word formation of neologisms: "semantic change, coinages, conversion or loans; reduction of elements, namely, abbreviations, backformation and shortenings; the addition or combination of elements, especially compounding, affixation, blending and acronymization". (Ahmad, 2000)

The best way to give the complete definition to the neologism is to place it to the dictionary.

According to Dubichinsky's (2008) point of view: "It is obvious, that the development of lexicography depends on the level of development of other sciences, such as informatics and linguistics. There exists the new openings in the philosophic understanding of the essense of meaning, its connection with the connection with notion and its lexicographic semantization. The researchers of the text, semantic word classes, componental and word formative, psycholinguistic and historical analyses are of great necessity now for the lexicography. These are no edges for the perfectness of the lexicography." (Dubichinsky, 2008)

\section{Methodology}

It is necessary to emphasize, that one of the future (though, it's already present) ways of the lexicography will be the foundation of the dictionaries of the new words, formed by one specific way of word formation.

In the modern word-formative theory there is practically no description of concrete unusual occasional way of word formation. There is also no dictionary, describing the words, composed by this or that type of word formation.

As a rule, any dictionaries of the new words fix the words, formed by different ways of word formation. The words, created by one type of word formation, are not grouped together. Even such grouping itself will give the dictionary a specific value.

Here we present some attempts and principles of the creation of the dictionary, describing one of the unusual ways of word formation - the holophrase.

Before creating such kind of dictionary, it is necessary to give the definition of this way of word formation separating it from others.

Any linguistic phenomenon has a philosophic, psychological - metaphysical background.

A good example of holophrase phenomenon is a speech of the children, just starting to talk. The world, which is originally not separated, first is defined by one word and then is started to differentiate.

In the 1960s, investigating the child's speech, the psycholinguist Martin Braine (1963; 1971) noticed that the single words, which the child starts to pronounce gradually embodied the communicative functions of entire phrases. Danesi (2003) writes: "the child's word "dada" could mean 'Where is daddy?' 'I want daddy,' etc. according to situation. He called them holophrastic, or one-word, utterances." (Danesi, 2003)

As Villierses (1979) writes: "The problem of the holophrase [is] that we have no clear evidence that the child intends more than he can express at the one-word stage."(J. De \& P. De Villiers, 1979) 
Here is Cole's (2004) point of view: "The single word in conjunction with the gestures and facial expressions is the equivalent of the whole sentence. By this account, the single word is not a holophrase, but one element in a complex of communications that includes nonverbal actions." (Cole, 2004).

One more psychological phenomenon, influencing the appearence of holophrastic constructions (HC), is the blockmaking of human mind. The often repetition of this or that expression or terms leads to its blockmaking and standartization. Human mind is disposed to thinking by blocks and stereotypes. The repetition of some definite structures leads to getting used to them and having some hypnotic affect. Here is the point of view of one specialist in psychology and rhetoric Sheinov (2003): "the immersion of the communicator into hypnotic condition is characterized by using the monotonously repeated phrases, causing the feeling of calm, relaxation and comfort" (Sheinov, 2003).

So, the holophrase is a way of word formation, when the new word appears as a result of combining the sentence or concept into one word.

\section{Results}

In opposition to child's ability to express the meaning of the whole phrase by one word, the modern authors use multiword formations to express one meaning. Here are several examples from the books of Kingsbury (2001): "And right now - to be perfectly honest - you are letting it happen. You and Miss Meet - You - Friday - Morning - Same - Time - as - Usual" (Kingsbury, 2001); Packer (2002) writes: "How could he have known I was from Madison? Was there a never - left - home look about me? A never - left - home, never - moved - from boyfriend - to - boyfriend, never surprise - anyone look?" (Packer, 2002).

There exist already several realizations of one way formation dictionary (Izotov \& Hvastova, 2010), (Izotov, 2011), (Izotov \& Kovyneva, 2011).

The main figure of any dictionary is a dictionary entry. Its volume may differ a lot - depending on the type of the dictionary and its tasks. But every dictionary entry possesses the title word. As for the dictionary of $\mathrm{HC}$, the title word will be represented by the same construction.

The required condition of the dictionary entry is the establishing of the meaning of the new word. In case this component is missed, the value of the dictionary composition is lowed. In the majority of cases the meanings of holophrastic constructions are established by the meanings of their components. One example from Kingsbury (2001): "What? Miss Too - Busy - to - Come follows Michigan football? (Kingsbury, 2001) - Too busy to come.

It is not so hard to establish the syntactical function of $\mathrm{HC}$ and its coordination with the part of speech. Here are four examples from Kingsbury (2001): "Beth was one of those If - I - get - lonely - I'll get - a - dog women..." - An attribute; part of speech - mixed, when the base of HC is a complex sentence. (Kingsbury, 2001); Roberts (2001): "And it was sweet to find herself the object of a teenage boy's crush - at - first - sight" - An object; a noun (Roberts, 2001); Martin (2002): "I realize his lordship wasn't the most popular man in London? But I can't say there were many who out - and out loathed him" - An object; an adverb (Martin, 2002); Packer (2002): "How could he have known I was from Madison? Was there a never - left - home look about me? A never - left - home, never - 
moved - from boyfriend - to - boyfriend, never - surprise - anyone look?" - An attribute; a participle (Packer, 2002).

There are some specific problems, which occur with the process of foundation of this dictionary. One of them is a problem of introduction of holophrastic construction into the dictionary. The words, created by this way of word formation are usually polycomponental. Does it mean that there should be as many introductions into the dictionary, as many words the basic holophrastic construction consists of? The answer is doubtfully positive. The introduction should be only one - by the first word in the construction.

As for the context of usage of $\mathrm{HC}$, then it is usually limited by the sentence, where $\mathrm{HC}$ is used.

\section{Conclusion}

Finalizing the presentation of the idea of the dictionary of HC, I want to demonstrate the examples of dictionary entries and some principles, according to which the dictionary entries are constructed. First comes the title word (or the HC itself), then the part of speech, which the HC is coordinated with, context of usage, the name of the author, the title of the literature handiwork, page and comments.

You-Know-Who. You know who; a well known person; pronoun

"Hang on - this hasn't got anything to do with Vol - - sorry with You-Know - Who, hasn't it?" (J. Rowling, 1999, p.16)

Black-paper-covered. Black paper covered; smth. covered with black paper; participle; "I came an errand one cloud - blowing evening

To a sab - built, black-paper-covered house...” (R. Frost, 1975, p.174)

So the dictionary of $\mathrm{HC}$ will make a double function: 1) systematize the theoretical material about this way; 2) present the real possibilities of the analysed way of word formation.

The HC dictionary emphasizes the new opening in the philosophic understanding of the sense of meaning and its connection with the lexicographic semantisation.

\section{References}

Alego, J. (1991). The International Dictionary of Neologisms. Fifty Years among the New Words: A Dictionary of Neologisms, 1941-1991. Cambridge, UK: Cambridge University Press.

Ahmad, K. (2000). Neologisms, Nonces and Word Formation. In Heid, U., Evert, S., Lehmann, E. \& Rohrer, C. (Eds.). Proceedings from The 9th EURALEX Int. Congress held in Munich, Germany, August 8-12, 2000 (Vol II.). Munich, Germany: Universitat Stuttgart.

Cole, M. (2004). The Development of Children. London, UK: Macmillan.

Dubichinsky,V. (2008). Lexicographiya russkogo yazyka: uchebnoje posobije [Lexicography of the Russian Language: students' book]. Moscow, Russia: Nauka-Flinta. 
Danesi, M. (2003). Second Language Teaching. New York, NY: Springer. http://dx.doi.org/10.1007/978-94-010-0187-8

Frost, R. (1975). The Poetry of Robert Frost. New York, NY: Henry Holt and Company, LLC.

Kovyneva, I. (2007). Holophrasis kak sposob slovoobrazovaniya v russkom yazyke [Holophrase as a way of word formation in the Russian language] (Doctoral dissertation). Oryol, Russia: Oryol State University.

Izotov, V. (2006). K voprosu ob irrealnyh sposobah slovoobrazovaniya [About irreal ways of word formation]. Word formation as a fact, 4 .

Izotov, V. (2006). O tipah slovarej novyh slov [About the types of new words dictionaries]. Polyphilology, 6.

Izotov, V. \& Kovyneva, I. (2011). O lexicographicheskom aspecte neusualnyh sposobov obrazovaniya [About the lexicographic aspect of unusual ways of word formation]. Intracultural communication: theory and practice, 3 (3). Kursk, Russia (Informregister 0321100911).

Izotov, V. \& Hvastova, E. (2011). Razdvinutye gorizonty: Slovar pljurativov V.Vysotskogo [Expanded horizons: the dictionary of plurals of V.Vysotskij]. Word and dictionary. 12 (12). Kharkov, Ukraine.

Kingsbury, K. (2001). A Time to Dance. New York, NY: Thomas Nelson.

Martin, K. (2002). Fanning the Flame. New York, NY: Pocket Books .

Villiers, J. \& Villiers, P. (1979). Language Acquisition. Cambridge, MA: Harvard Univ. Press.

Packer, A. (2002). The Dive from Clausen's Pier. New York, NY: A Division of Random House.

Roberts, N. (2001). Villa. New York, NY: Jove Books.

Rowling, J. (1999). Harry Potter and the chamber of secrets. New York, NY: Scholastic.

PMCid:PMC1297042

Sheinov, V. (2003). Ritorika [Rhetoric]. Rostov on Don, Russia: Feniks. 